\title{
A Cognitive Perspective on Autofictional Writing, Texts, and Reading
}

\author{
Alexandra Effe and Alison Gibbons
}

The early twenty-first century is witnessing a boom in autofiction, with the genre now a global publishing trend that enjoys cultural prestige and such a prosperous readership that the moniker has become its own marketing tool. Scholarly accounts have typically taken a literary critical perspective, positioning autofictions as contemporary cultural products. Marjorie Worthington argues that autofiction is "a symptom of the declining cultural capital of the traditional figure of the author" $(2018,6)$, while Hywel Dix suggests three impetuses for the autofiction boom: "a relative increase in the status of women's writing; the changing nature of the publishing industry, including the advent of self-publishing; and the saturation of the print and broadcast media with so-called 'reality' narratives" $(2018,10)$. What is missing from these perspectives is an account of autofiction not only as a cultural artifact in and of itself but also as part of a more holistic literary event, which includes writer and readers.

\footnotetext{
A. Effe $(\bowtie)$

University of Oslo, Oslo, Norway

e-mail: alexandra.effe@ilos.uio.no
}

\section{A. Gibbons \\ Sheffield Hallam University, Sheffield, UK}

(C) The Author(s) 2022

A. Effe, H. Lawlor (eds.), The Autofictional, Palgrave Studies in 
Studies of autofiction frequently make claims about readers and the reading experience: Worthington writes of "the constantly shifting reading strategies that autofiction requires" $(2018$, 5); Frank Zipfel names "the specificity of autofiction" in a narrow definition as "the unresolvable paradox of $[\ldots]$ contradictory reading instructions" $(2005,36)$; and Henrik Skov Nielsen describes autofictional texts as "overdetermined" because they present themselves, either at the same time or at different times, "as both fiction and nonfiction" (2011, 131). Consequently, many critics argue that reading autofiction involves an oscillation between, or a combination of, two attitudes of reception, what Lejeune (1989) saw as different contracts or pacts of reading: autobiographical and fictional. We agree with these critics' theoretical instincts. Nevertheless, to advance understanding of autofiction, and to evidence claims about the autofictional text and its reading experience, such assertions require further substantiation.

The role of the author as producer of autofiction is discussed less frequently, but is equally subject to critical conjecture. Siddharth Srikanth, for instance, defines autofiction as "a work in which the author is the protagonist, in which the author's biographical background and life experiences inform the nonfictionality of the work and in which the author combines fictionality and nonfictionality at length for his or her purpose" (2019, 353; our emphasis). These purposes, however, are unearthed through Srikanth's own critical interpretation, leading him to suggest that J. M. Coetzee "uses" Summertime - which revolves around the idea that a biographer interviews acquaintances of the recently deceased author"to evaluate his own writing" (360). Another way in which autofictional writing is approached is through theories and studies of creative writing. Celia Hunt considers the personal gains of self-exploration through reflexive writing as work-in-progress and argues that autofictional writing "reveals itself to be a cognitive-emotional tool with, potentially, very powerful therapeutic benefits" $(2018,193)$. Her study does not, however, consider the intentions of published writers of autofiction. Similarly, Amelia Walker is interested in how autofictional texts can be used in teaching "personal reflective writing" $(2018,206)$.

In this chapter, we redress the balance between attention to autofictional texts, autofictional writing, and autofictional reading. We apply a cognitive and empirically grounded approach which offers a holistic account of the autofictional literary experience. The approach is holistic in 
that it not only explores the textual and narrative dynamics that signpost autofiction as at the same time autobiographical and fictional; it additionally, and significantly, considers both production and reception. We draw on three case studies: Philip Roth's The Facts (1988), Olivia Laing's Crudo (2018), and Ben Lerner's 10:04 (2014). These texts exhibit different degrees of fictionality and have different affordances and effects. Roth's The Facts reads like a primarily autobiographical narrative, signaling fictionality through the letters which frame it, one by a "Roth" authorcharacter $^{1}$ and the other by a fictional character named Nathan Zuckerman who is often interpreted as Roth's alter ego. Laing's Crudo blends the narrative events of the author's real life in 2017 with the biographical details of the real, but by then long deceased, writer Kathy Acker. While Ben Lerner's 10:04 features a first-person narrator referred to once as "Ben" who shares much of the author's personal history, the narrative is predominantly fictional. Taken together, these works illustrate some of the variety of autofictional texts. Based on empirical studies concerning the processing of factual and fictional modes of discourse and accounts of the writing process by authors, we offer definitions of autofictional reading and writing. These definitions provide the basis for our discussion of the cognitive affordances and effects of autofictional modes in The Facts, Crudo, and 10:04.

\section{Autofictional Reading}

Building on Alison Gibbons's argument that autofiction "is not only a literary genre, but also a reading strategy" $(2019,411)$, we suggest that there is a distinct mode of autofictional reading which responds to a text's invitations to be read as simultaneously fictional and factual. Readers draw on cognitive schemata to guide their expectations and responses in reading. Cognitive schemata are abstract representations of knowledge gained from experience about objects and situations; this knowledge helps to guide actions and expectations in the world (Stockwell 2019, 103-118). Schemata also help in managing reading expectations and behavior, with readers possessing schemata for genre, text-type, text-media such as digital fiction, and specific narratives/texts (e.g. Bell 2014; Cook 1994; Gibbons 2016; Mason 2019). Empirical studies indicate that readers also have cognitive schemata related to fiction and non-fiction. We therefore claim that 
readers approach an autofictional text with two kinds of acquired cognitive schemata: those for factual and those for fictional texts.

Evidence that genre expectations can influence how readers approach, process, and build mental representations can be found in cognitive, experimental, and developmental psychology (see Gibbons 202lb). Several studies have tested whether readers' perceptions of fictionality influence engagement, with participants informed in paratextual instructions that the same extract is either factual or fictional. Differences in reading times between the two conditions demonstrate that reading non-fiction involves prioritizing causal-situation information and disregarding contradictory or irrelevant details, while reading fiction entails building more detailed mental representations (Zwaan 1994), and that participants are more likely to scrutinize factual texts (Green et al. 2006). Deborah A. Prentice and Richard J. Gerrig (1999) took a different experimental approach by manipulating the details of a story to create two versions: one which primarily contained "contextual details," specific to the fictional storyworld; and another that primarily contained "context-free assertions," which generally hold and conform to real-world knowledge. Their results again indicate that readers process non-fiction more systematically than fiction.

Torsten Pettersson's (2016) study is relevant, in terms of this chapter's concerns, as he presented participants with an extract from the first volume of Karl Ove Knausgaard's My Struggle series, a now canonical example of contemporary autofiction. Pettersson manipulated paratextual framing to guide participants' expectations as to a text's factual or fictional status. The response data Pettersson collected was both quantitative and qualitative; the latter being particularly unusual as studies in experimental psychology generally collect the former. Based on the qualitative data, Pettersson concludes that "fiction stories are described as a source of knowledge, insight, or increased mental ability" (2016, n.p.). His qualitative analysis therefore adds further support for the influence of readers' schematic expectations about fictionality and factuality; in this case, the bearing that these expectations can have on the experience of reading autofiction.

One potential drawback of bringing such empirical data to bear on a discussion of autofiction is that, because experimental studies require easily controllable variables, they tend to take a binary view of factual and fictional genres. Such a view is ultimately insufficient for understanding autofiction, as well as autofictional modes of writing and reading. Text 
comprehension studies demonstrate that sentences that involve inconsistencies or clashes in fictionality conditions (e.g. when a fictional character is said to meet a real person) are easily detected (Yang and Xue 2014, 2015). On the one hand, this means that readers should be able to distinguish between textual beings that are known to them as representing real people and those that are known to be fictional inventions. The same logic thus applies to other aspects of the text, such as real versus fictional events, places, and so on. On the other hand, this does not resolve the ambiguity of autofiction, wherein the author-character can bear the real author's name but in every other respect be invented.

Indeed, empirical studies show that factors other than framing and realworld reference of entities or events also affect reader engagement. Two recent neuroimaging studies show, for example, that different neural patterns are activated when reading about real people and fictional characters (in the former case, emotional engagement is higher), but also that the decisive factor seems not to be fictionality but personal relevance (Abraham and von Cramon 2009; Abraham, von Cramon, and Schubotz 2008). Two earlier studies (Seilman and Larsen 1989; Larsen and Seilman 1988) find that literary/fictional as opposed to expository texts create more personal remindings (the technical term for spontaneous recollection of experiences) in which the reader has an active role rather than simply being an observer. Together, then, these experiments show that the cognitive operations involved in reading-whether fictional, factual, or hybrid texts-are too complex to be explained through framing alone.

Overall, the findings of empirical studies show that readers have cognitive schemata related to fiction and non-fiction and this affords credence to existing literary critical intuitions about reading autofiction (discussed in this chapter's introduction). As well as generating a combination of or oscillation in reading stances, however, autofictions often contain moments of ambiguity in which the reference to or departure of an element to or from the real world cannot be resolved. Consequently, we define autofictional reading as a mode in which readers approach the text with two overarching schemata, either in combination or in quick oscillation, and in which they often experience moments of tension or uncertainty about the communicative intention (fictionality/factuality) and/or ontological status (fictive or real) of entities and elements. The factual schema leads readers to approach a text for information about the real world, the real author, and to evaluate the relevance of this information for themselves and their own lives. The fictional schema encourages readers to approach the text 
for diversion and aesthetic pleasure, for indirect knowledge and general truths: it means paying attention to thematic meanings and refraining from applying standards of empirical verification or falsification. The effects of such tensions and uncertainties have not been tested, but we offer suppositions about potential effects in the subsequent discussion of our three case studies.

\section{Autofictional Writing}

Just as we maintain that there is a specific autofictional mode of reading, we also argue that there is a mode of autofictional writing. Autofictional writing refers to the intentional production of a text both as autobiographical and as fictional, and the complementary intention that the text be recognized as such. The author aims to represent their self, or a dimension of their self, while also purposefully taking creative liberties in the act of self-narration. This is what we call an act of autofictionalization. ${ }^{2}$ Autofictional writing is thus distinct from lying and misremembering-as Henrik Skov Nielsen, James Phelan, and Richard Walsh (2015) note for fictionality generally-and aims at something in addition to selfrepresentation. Potential goals of the intentional act of autofictionalization include those associated with fictional modes in general (e.g. aesthetic pleasure, indirect learning, general or indirect truth), but there are also goals particular to the autofictional mode. These include creative, explorative thinking in the pursuit of self-understanding, self-performance and self-creation, and readerly positioning (with the aim, for example, of anticipating objections or of inviting reader engagement).

As yet, there is no empirical research into autofictional writing, though Hunt's observations on the therapeutic effects of fictionalizing strategies in creative life writing constitute a step in this direction. On the basis of students' self-reports and with recourse to comments by writers like Doubrovsky, Hunt argues that autofictional writing means "work[ing] in the autobiographical space with fictional/poetic techniques" $(2018,192)$, and creating a position of simultaneously being inside oneself and observing the self from the outside $(2004,156 ; 2018,185)$. This is possible if writers suspend Lejeune's autobiographical pact in favor of a pact with themselves that entails "loosen[ing] control of the writing process so that space for the imagination opens within an autobiographical frame" (Hunt 2018, 190-191). The ways in which Philip Roth, Olivia Laing, and Ben Lerner describe their practice in interviews support Hunt's assertions. 
Furthermore, the authors' commentaries on The Facts, Crudo, and 10:04 show their aims and strategies to be more diverse than those which interest Hunt, and allow conclusions to be drawn about the affordances of autofictional writing. While autofictional texts in particular make it difficult to draw a purposeful boundary between statements within the text, for example, by authorial alter egos, and statements outside the partially fictional universe, we focus on the latter in this section and consider the former in the next.

Throughout his oeuvre, Philip Roth has not only created fictionalized self-representations of different degrees but also written autobiographically without markers of fictionality. The Facts (1988) is more strongly and more explicitly autobiographical: in interviews, Roth repeatedly attests to the "facts" in this particular text but also stresses that he could not have presented them without fictional qualifiers and challenges. The fictive character Zuckerman speaks in a fictional letter at the end of the book, voicing, and thus anticipating, objections to Roth's autobiographical narrative. In interview, Roth speaks of this as "covering [all the] bases" (Roth 1988a, 223) but also says that he intended for Zuckerman's countervoice to give readers interpretative possibilities and alternative perspectives in order to "enlarge [their] perception of the book" (224). Roth's comments reveal both other- and self-directed intentions. For the writer, according to Roth, Zuckerman as autofictional countervoice constitutes "a genuine challenge to the book" that comes from Roth himself (223). Roth began writing the facts, he explains, after what he describes in the book as "minor surgery" that "turned into a prolonged physical ordeal that led to a depression" and carried him "to the edge of emotional and mental dissolution" (Roth 1988b, 5). His aim, as he characterizes it in his book, was to "retrieve [his] vitality, to transform [himself into himself]" by way of "rendering experience untransformed." Zuckerman's voice challenges the endeavor of retrieving bare facts and an untransformed self. The Facts appears to constitute Roth's own attempt at figuring out where he stands between the conflicting positions of his two alter egos-the one equating fictionalization with lying and disguise, and longing to find a self that is untransformed, and the other acknowledging the impossibility of such an attempt as he conceives of acts of fictionalization as self-creation and, in consequence, of autofictional writing as a means of insight into himself and as a more truthful kind of autobiography. 
Crudo is the result of Olivia Laing's decision "to take [her] own life and times and transpose them into the Kathy Acker person," motivated by the wish to "see what would happen if [she] recorded everything that was going on around [her], from [her] own wedding to Trump's tweets threatening nuclear war, from the perspective of this cartoonish, hyperanxious, paranoid figure" (Laing 2018c). Her writerly process purportedly involved writing every day, combining reflections on her own daily personal life, the representation of world news in the media (including on social media), and entwining this with the late Kathy Acker by randomly flipping through Acker's novels until she found something that spoke to the day's news (Laing 2018b). Laing combines her own identity, voice, perspective, and experience with those of someone else. She expresses reservations about the term "autofiction," ${ }^{3}$ but what she describes can nonetheless be understood as a strategy with cognitive affordances characteristic of autofictional writing. She characterizes these in terms of liberation and self-transformation, and as effecting a distancing and displacement that comes with new perspectives on self and world. The ploy of writing as or through Kathy, Laing says, allowed her to get away "from both direct reportage and labored, self-absorbed confessional writing," by adopting the perspective of "a character that could observe the turbulence [of the summer of 2017] in an exaggerated, frenetic, paranoid way," "a made-up perspective from which to view a real moment" (Laing 2018b). Laing, moreover, describes autofictional writing as enabling her to speak and think more freely, and even to transform herself, at least for the duration of writing. "Writing as Kathy," Laing says, "as this hybrid Frankenstein composite of me and Acker," "to invent the character and to help [her]self to the ravishing grab bag of Acker's own work," was "immediately liberating," allowing her to "say anything," to "zigzag between topics," and to "talk about both the political and the personal without getting bogged down" (Laing 2018b). The autofictional mode, in sum, allows Laing to develop new perspectives on herself and the world, and to, momentarily at least, transform her (experience of) self.

Ben Lerner explains in interviews that his interest lies not in the distinction between reality and fiction but in what stories do (David 2016). He is concerned with "how we live fictions, how fictions have real effects, become facts in that sense, and how our experience of the world changes depending on its arrangement into one narrative or another" (Lerner 2014 b). Lerner, therefore, explains autofictional self-referentiality as an attempt to be sincere rather than ironic, which for him entails exploring 
"how fiction functions in our real lives-for good and for ill" rather than "mocking fiction's ability to make contact with anything outside of itself" (Lerner 2014b). Autofictional writing can constitute such a sincere exploration of the effects of stories, including fictional stories, in the author's life, and in that of the reader. These real-world effects of storytelling are what Lerner's autofictional practice arguably not only depicts but also aims to generate. The narrator of Lerner's book refers to "the utopian glimmer of fiction" $(2014 \mathrm{a}, 54)$, and Lerner's reflections on the potential of (fictional) storytelling invite an explanation of this utopian potential in terms of the cognitive affordances and effects of an autofictional mode.

Ultimately, Roth, Laing, and Lerner each talk about their intentions and writing strategies in terms that reveal the impulse of autofictional writing. In the next section, we examine how their books activate factual and fictional schemata, and in consequence create specifically autofictional effects.

\section{Autofictional Texts}

The Facts, Crudo, and 10:04 all invite modes of autofictional reading. Because works of autofiction are by definition self-reflexive, albeit to different degrees, they often reveal how writers of autofiction conceptualize their craft: what they think about autobiographical writing, how they conceive of their act of fictionalization, and especially the act of autofictionalization. In this section, we link the formal makeup of these three autofictional texts to intimations of intentions in autofictional writing and the cognitive experience of autofictional reading.

\section{Philip Roth}

The title of Philip Roth's The Facts foregrounds the work's global factuality, while its autofictionality is made apparent by its subtitle " $A$ Novelist's Autobiography." While its primary generic coding is "autobiography," the pre-modification carries a double meaning: on the one hand, it signals possession-the self-narration and the life being storied belong to the novelist Philip Roth; on the other hand, it intimates that techniques of fictionalization and literary craftsmanship have been used in the telling of Roth's life story. Roth also presents readers with an epigraph attributed to "Nathan Zuckerman, in The Counterlife," one of several earlier novels by Roth in which Zuckerman appears as a fictional alter ego. ${ }^{4}$ In the epigraph, 
Zuckerman-or Roth-comments on the cross-influence of life and text: "And as he spoke, I was thinking, the kind of stories that people turn life into, the kind of lives that people turn stories into" (original emphasis). By quoting his fictional character in an epigraph-a type of discourse commonly reserved for the words of real people-Roth puts the distinction between fictional characters and historical people under threat. At the same time, Roth signals through the epigraph that he uses Zuckerman as mouthpiece. The effect is an ontological ambiguity between the author and the character, the factual and the fictional, which gestures toward the need to engage with The Facts through an autofictional mode of reading.

Framing the central narrative of The Facts are two letters: the first, from "Roth" to Zuckerman; the second, Zuckerman's reply. In their letters, the pair discuss the truth value of this ostensible manuscript in relation to Roth's historical creation of explicitly fictionalized author surrogates. The discussion is apt, since, as Berryman puts it, "Roth has long used this figure [Zuckerman] to hold a dialogue with himself" $(1990,177)$. The framing letters constitute invitations for autofictional reading as they highlight the difference between Roth, as real author, and these two textual impersonations. This invitation is intensified through the letters' content: "Roth" and Zuckerman debate the role of acts of imagination in memory, the relation of these acts to truth, and the power of fiction to (trans)form the self.

In the opening letter, "Roth" recognizes that what defines a fact is contentious, especially in autobiographical narration, as "the facts are never just coming at you but are incorporated by an imagination that is formed by your previous experience," and that "[m]emories of the past are not memories of facts but memories of your imagining of the facts" $(1988 \mathrm{~b}, 8)$. In contrast, in his previous use of Zuckerman as a character in his fiction-in acts of autofictionalization, to use our terms - Roth, by his surrogate's account, set himself the following rules: "imagin[ing] things not quite as they had happened to me or things that never happened to me or things that couldn't possibly have happened to me happening to an agent, a projection of mine, to a kind of me" (6).

The "Roth" and Zuckerman surrogates present differing opinions on the affordances and effects of acts of autofictionalization. For "Roth," they constitute "masks, disguises, distortions, and lies" (6), from which he claims to want to move away. Zuckerman, on the other hand, expresses doubt in his reply about whether such undisguised autobiography is possible, all the more so for a writer like Roth who has been formed or 
transformed by writing in autofictional modes: "My guess is that you've written metamorphoses of yourself so many times, you no longer have any idea what you are or ever were. By now what you are is a walking text" (162; original emphasis). Zuckerman highlights the affordances of autofictional writing for self-insight and a more honest form of selfrepresentation. He is of the opinion that "in the fiction you can be so much more truthful" (162), that "there is mystery upon mystery to be uncovered once you abandon the disguises of autobiography and hand the facts over for imagination to work on" (185), and that it is "through dissimulation that you find your freedom from the falsifying requisites of 'candor"' (185; original emphasis). The dispute between the two alter egos warns readers against naively mining Roth's oeuvre for biographical details or criticizing it for omissions or misrepresentations. ${ }^{5}$

While the letters comment on acts of autofictionalization, they also constitute such an act. The ploy functions to counsel readers against reading The Facts as straightforwardly autobiographical (or, indeed, as straightforwardly fictional). The Facts does contain verifiable details: biographical events, such as the death of Roth's first wife in a car accident; references to Roth's own work on his journey to becoming a successful writer; mentions of published journalism about and critical responses to his life and work. Nevertheless, "Roth" is at pains to emphasize the fallibility of his memories. Recounting his interview for a place at Bucknell University in 1951, "Roth" writes that his interviewer was "a courteous middle-aged woman whose name I've by now forgotten" (43). To cover the gap in memory, "Roth" openly resorts to invention: "Miss Blake, let's call her" (43). Later, he claims to have completely forgotten a disciplinary hearing in front of the student-faculty Board of Publications: "I don't remember it at all and was only recently reminded that it took place by my former teacher, Mildred Martin" (67). To piece the episode together, he requested that "Mildred-who is now eighty three- $\operatorname{sen}[\mathrm{d}]$ me entries from her 1953-1954 journals" (67), some material from which has purportedly been included in The Facts (69). While some elements of The Facts necessarily engender a factual schema for reading, this is undercut somewhat by such blatant memory blanks. Even in the closing letter, Zuckerman casts doubt on the wholesale veracity of The Facts, advising the author "I think you must give Josie her real name" (178); "Josie" being the characterpseudonym given to the first wife of "Roth" in the book.

Acts of fictionalization and autofictionalization throughout The Facts continually disrupt reading the book through an uncomplicatedly factual 
schema. Rather, the book openly debates and problematizes the distinction between factual and fictional schemata, asking instead to be read in an autofictional mode. The countervoices provided by "Roth" and Zuckerman serve to destabilize Roth's self-presentation, allowing him to challenge his own memory and self-construction, and inviting readers to explore a range of interpretative possibilities.

\section{Olivia Laing}

Crudo is Olivia Laing's debut novel and a departure from her established profile as a writer of non-fiction. The work bears no subtitle providing its generic description but is marketed, on online bookselling sites and in published reviews, as a novel. Its bizarre epigraph- "The cheap $12 \mathrm{inch} \mathrm{sq.}$ marble tiles behind the speaker at $U N$ always bothered me. I will replace with beautiful marble slabs if they ask me" (original emphasis)—is unattributed on the page itself but is later identified, in the book's appended list of sources (2018a, 135), as words tweeted by Donald Trump (3 October 2012). The epigraph therefore sets up a tension in terms of the book's overarching fictional schema. Trump's tweet is a context-free assertion of sorts; here, its extratextual reality appears to enter into the fictional university of Crudo.

The novel's opening is composed as a curious combination of both first and third person: "Kathy, by which I mean I, was getting married. Kathy, by which I mean I, had just got off a plane from New York. It was 19:45 on 14 May 2017" (1). As the narrative continues, readers learn that "Kathy had written several books-Great Expectations, Blood and Guts in High School, I expect you've heard of them" (1). The named texts, particularly the latter, are easily identifiable to informed readers as Kathy Acker's published works. However, as the real Kathy Acker died in 1997, the 2017 airport arrival described at the start of Crudo is a logical impossibility, at least according to a factual, biographical schema. In consequence, the narrator and "Kathy," at the start of the novel and at various points thereafter, come together and fracture apart in fluctuating subjective transpositions. As such, the opening signals, at least to one reviewer, that "the novel is several things at once: a work of autofiction detailing key events in Laing's life, a counterfactual fiction in which Kathy Acker is alive and getting married and a rigorous piece of fictional appropriation" (Kitamura 2018, 10). The play of subjectivities so central to Crudo is at the heart of its autofictional ambiguity. While Kathy Acker was a real 
person, the persona in Crudo is fabricated by, and merged with, Laing; the "Kathy" /I persona, therefore, represents freedom to depart from traditional autobiographical representation, including aims at factual accuracy. Crudo thus demands an autofictional mode of reading: readers must oscillate between imagining "Kathy" as a fictionalized counterpart of Kathy Acker reacting to the real events of 2017 and simultaneously attributing these reactions, as belonging, and happening, to Laing herself.

As mentioned, in interviews Laing has openly discussed her compositional method for Crudo. In the early pages of the novel, her writing process is transposed into the routine of "Kathy": "Kathy was writing everything down in her notebook, and had become abruptly anxious that she might exhaust the present and find herself out at the front, alone on the crest of time" (8). In Crudo, engagement with "the present" takes place largely through digital media, from which Laing quotes freely and in so doing weaves real events and, more importantly, the voices of real people, into the fabric of her book. Worried about the increasingly tense relationship between the United States and North Korea, for example, "Kathy" decides to consult Trump's Twitter account:

It was worse than she'd expected. He was retweeting Fox News about jets in Guam that could fight tonight, but he was also taking time out to trashtalk the FailingNewYorkTimes. My first order as President was to renovate and modernize our nuclear arsenal. It is now far stronger and more powerful than ever before ...... Hopefully we will never have to use this power, but there will never be a time that we are not the most powerful nation in the world! (42-43)

The first-person voice here once again belongs to Donald Trump via Twitter (9 August 2017). The list, "Something Borrowed," at the end of Crudo (135-141) discloses appropriated material from real-world textual sources included in the book. A significant number are from Kathy Acker's work; others are taken from Twitter as well as news and magazine sources. Although Acker fans might notice the inclusion of the dead writer's material, it seems unlikely that readers will be familiar with all of Laing's appropriated sources. Factual and fictional materials thus repeatedly intrude into Crudo, at times imperceptibly. The appended source list does acknowledge them, however, and, in so doing, makes readers aware of how Laing merges modes of discourse (news, social media, autobiography, and novel) 
and voices (Acker's, Laing's, and those of fictional characters as well as other real-world people).

In Crudo, "Kathy" thinks, "[ $\mathrm{t}]$ his was the problem with history, it was too easy to provide the furnishings but forget the attitudes, the way you became a different person according to what knowledge was available, what experiences were fresh and what had not yet arisen in a personal and global frame" (82). Capturing the attitudes of other people is, according to "Kathy" / Laing, "the province of the novel, that hopeless apparatus of guesswork and supposition, with which Kathy liked to have as little traffic as possible. She wrote fiction, sure, but she populated it with the already extant, the pre-packaged and ready-made"; "it was economic also stylish to help yourself to the grab bag of the actual" (84). Appropriated intertextual material and context-free assertions about 2017 intermingle with "Kathy"'s experiences of Laing's autobiographical life (such as her wedding). Crudo is driven consequently not only by acts of autofictionalization but a form of collective socio-historical commentary which, by placing Laing and "Kathy" in the wider context, seems to be an attempt to capture not only the events of 2017 but the spirit of the times.

Within Crudo, "Kathy" / Laing admits to longing for some sort of interpersonal liberation: "She was bored, [...] wanted novelty and heat, [...] wanted to unhook herself" (72). Writing, especially autofictional writing, seems to make this possible. Toward the end of Crudo, "Kathy" / Laing repeatedly stresses that "she c[an't] settle" (113), switches furniture, flats, cities, "want[s] a new coat, a new figure, a new lease of life," "want[s] someone else's life" (113). She realizes that this is possible in writing: "Writing, she can be anyone. On the page the I dissolves, becomes amorphous, proliferates wildly. Kathy takes on increasingly preposterous guises, slips the knot of her own contemptible identity" (125). Just as Zuckerman advises "Roth" in The Facts that freedom can be found only if the pursuit of autobiographical accuracy is abandoned, "Kathy"/Laing finds release by borrowing from the lives of others, both real and imagined.

Ultimately, Crudo's composition not only problematizes any reading that seeks to pigeonhole the work through a wholly fictional or factual schema; it also encodes the experience of living in a social media-saturated culture, in which reality and textual mediation are sometimes difficult to separate. The result is a disorientating literary experience-in other words, an autofictional effect. 


\section{Ben Lerner}

Ben Lerner's 10:04 is subtitled " $A$ Novel." The three-part narrative features two author figures, presented as fictionalized versions of Lerner. "Ben," the first-person narrator of the first and third parts, is a writer who lives in Brooklyn (as does Ben Lerner), writes one of Lerner's poems ("The Dark Threw Patches Down Upon Me"), and is working on a book that turns out to be 10:04 itself. Part two consists of one of Lerner's previously published short stories, featuring the second author-character, this time referred to in the third person as "the author," who has made a debut with a novel identifiable to readers familiar with Lerner's previous work as Leaving the Atocha Station-Lerner's first novel, published in 2011. Thus, while 10:04's subtitle immediately activates a fictional schema for readers, an autobiographical reading is simultaneously invited through the onomastic and biographical correspondences between author and protagonist and the references to actual publications that the author and character share. 10:04, in sum, signals an autofictional text and produces a corresponding reading mode.

There are, moreover, several instances within 10:04 in which the (real) effects of (fictional) stories are thematized. "Ben" is, for example, advised by a friend against writing "about medical stuff," since, the friend claims, "you believe, even though you'll deny it, that writing has some kind of magical power" and are "crazy enough to make your fiction come true somehow" (Lerner 2014a, 137-138). The narrator validates this allegation by first denying it and then confessing the dishonesty of his denial in the narration. In another instance, "the author" takes a stance against autobiographical readings of his/Lerner's first novel, but follows suit with the acknowledgment that, as the narrator of this book "was characterized above all by his anxiety regarding the disconnect between his internal experience and his social self-presentation, the more intensely the author worried about distinguishing himself from the narrator, the more he felt he had become him" (66). The act of (auto-)fictional distancing, these comments suggest, creates distance between author and narrator or character, but in turn transform the author. Through these instances of metanarrative commentary, 10:04 thus invites the kind of autobiographical, or rather autofictional reading, that the author-characters reject.

In the first pages of 10:04, Lerner sets up the premise that the book that "Ben" has been commissioned to write is 10:04 itself. At the end of 10:04's opening scene, a celebratory meal in a Manhattan seafood restaurant, 
"Ben" promises "a novel" to his fellow diner and publisher in which their own act of "eating cephalopods" will "become the opening scene" (4). The genre designator "novel" together with the word "scene" clashes with the metatextual information about the author's own process of writing. As the author-character is writing the very artifact we are reading, 10:04 must be seen as both an autobiographical narrativization of the writing process and a fictional representation of a writer-character. The clash demands combining or oscillating between the fictional and the autobiographical mode - a demand that is reiterated at intervals throughout the book. It is most apparent in other instances of indexicality; for example, when the narrator suggests, "say that it was standing there that I decided to replace the book I'd proposed with the book you're reading now, a work that, like a poem, is neither fiction nor nonfiction, but a flickering between them" (194). Lerner makes the movement from fictional story to real world materiality palpable even when the narrator puts before us the following image: "a bright glow to the east among the dark towers of the Financial District, like the eyeshine of some animal" (237). The light, we are told, comes from the Goldman Sachs building, and the narrator refers us to "photographs in which one of the few illuminated buildings in the skyline was the investment banking firm, an image," he notes in passing, "I'd use for the cover of my book" (237). Through this reference to the photograph, the book that "Ben" has been writing materializes in the reader's hands, at least if they have the US edition of 10:04, which features this very image on its cover. 10:04 is, in other words, a book "on the very edge of fiction" (237) - a book oscillating between the fictional and the autobiographical.

Elsewhere, we have both argued that 10:04 has the potential to affect how readers think, feel, and possibly act in the real-world context of climate change and globalization. Gibbons (2021a) stresses that 10:04 creates an "affective effect" (144) of the anticipated future for readers and that 10:04 "positions Ben's anxieties as already part of a reader's past and present" making the potential future apocalypse "feel more meaningful to readers" (142). Alexandra Effe (2021) argues that 10:04 "works toward change by calling on the reader to take action in reality" and that Lerner's text has high potential for inciting readers to do so as the autofictional dimension creates a feeling of direct relevance for readers in combination with the sense of possibility for transformation (739). Lee Konstantinou categorizes Lerner more generally in a group of "affective neorealists" $(2018,111)$, who aim to "facilitate new powers for fiction" (120). 
Empirical data on factual and fictional reading modes and Lerner's own reflections on autofictionalization offer a possible explanation for the potential cognitive-affective effects of his book.

In this chapter, we have argued that autofictional texts should not be considered in isolation but rather as part of a literary event that includes the intentional production of an autofictional mode of writing and a corresponding autofictional mode of reading. Empirical data-in the form of writers' self-reports in interviews and evidence from psychology concerning the cognitive-affective dimensions of fictional and factual reading modes - has enabled us to substantiate our claims and form theoretically and empirically grounded hypotheses about autofictional writing and reading. Writers' own reflections, both in interviews and within their works, provide insight into the motivations for and cognitive affordances of their acts of autofictionalization, from interrogating memories to coming to terms with living in a contemporary society in which social media fuels a post-truth culture and climate change creates an uncertain future. Furthermore, readers of The Facts, Crudo, and 10:04 are likely to recognize and feel the rootedness of these works in their real-world contexts, be that a single author coming to terms with their life and the reception of their work, the disorientation of our media-saturated contemporary culture, or the reality of climate change. This rootedness in reality is likely to create personal relevance which, empirical studies suggest, is linked to higher emotional involvement - that is, to an affective effect. The fictional dimension of autofiction, in turn, is likely to lead readers to create detailed mental representations and contemplate contradictory elements, such as different author avatars and different depicted realities. Such contemplation will also mean more critical, perhaps also more creative, engagements with the text, including the ways in which readers relate to autofictions and what changes they themselves might put into action in their lives. The cognitive and holistic perspective adopted in this chapter, combined with attention to the textual and paratextual apparatus of a work, has allowed us to draw out and to better understand such effects and affects. Especially in the light of the personal and psychological dimension of much autofictional literature, we believe that this perspective is ultimately best placed to account for the affordances and affective resonances of autofiction as a holistic literary experience. 


\section{Notes}

1. When names are placed in inverted commas, we are referring to characters and author-avatars as textual beings in our case studies.

2. To our knowledge, our use of the term is novel, although Walker (2018) speaks of "autofictionalizing reflective writing strategies" (in the title of her chapter).

3. Laing feels that the term "autofiction" diminishes her understanding of novels as "an intimate communication between writer and reader with personal stakes” (Laing 2018b).

4. Berryman (1990) discusses Zuckerman as Roth's self-portrait throughout the author's work.

5. The Facts can thus be seen as a reply to select Jewish-American readers, reading what Roth intended as satires as autobiographical, criticizing him for betraying a Jewish community, and accusing him of self-hatred. The Facts seems to put the record straight, but the autofictional dimension also qualifies "the facts" that The Facts provides. For an account of The Facts as an ambiguous act of righting the record, see also Wirth-Nesher (2007, 158-64).

\section{Works Cited}

Abraham, Anna, and D. Yves von Cramon. 2009. Reality = Relevance? Insights from Spontaneous Modulations of the Brain's Default Network when Telling Apart Reality from Fiction. PLoS One 4 (3): 1-9.

Abraham, Anna, D. Yves von Cramon, and Ricarda I. Schubotz. 2008. Meeting George Bush versus Meeting Cinderella: The Neural Response When Telling Apart What is Real from What is Fictional in the Context of Our Reality. Journal of Cognitive Neuroscience 20 (6): 965-976.

Bell, Alice. 2014. Schema Theory, Hypertext Fiction and Links. Style 48 (2): 140-161.

Berryman, Charles. 1990. Philip Roth and Nathan Zuckerman: A Portrait of the Artist as a Young Prometheus. Contemporary Literature 31 (2): 177-190.

Cook, Guy. 1994. Discourse and Literature. Oxford: Oxford University Press.

David, Thomas. 2016. Ben Lerners Roman 22:04: Hat es dieses Brooklyn je gegeben? http://www.faz.net/aktuell/feuilleton/buecher/autoren/ben-lernerueber-seinen-roman-22-04-14028724.html. Accessed Mar 30, 2021.

Dix, Hywel. 2018. Introduction: Autofiction in English: The Story so Far. In Autofiction in English, ed. Hywel Dix, 1-23. Cham: Palgrave Macmillan.

Effe, Alexandra. 2021. Ben Lerner's 10:04 and the "Utopian Glimmer of [Auto]fiction." Modern Fiction Studies 67 (4): 739-757. 
Gibbons, Alison. 2016. Multimodality, Cognitive Poetics, and Genre: Reading Grady Hendrix's Novel Horrorstör. Multimodal Communication 5 (1): 15-29. - 2019. The 'Dissolving Margins' of Elena Ferrante and the Neapolitan Novels: A Cognitive Approach to Fictionality, Authorial Intentionality, and Autofictional Reading Strategies. Narrative Inquiry 29 (2): 389-415.

- 2021a. Metamodernism, the Anthropocene, and the Resurgence of Historicity: Ben Lerner's 10:04 and 'the utopian glimmer of fiction.'. Critique: Studies in Contemporary Fiction 62 (2): 137-151. https://doi.org/10.108 0/00111619.2020.1784828.

- 2021b. 'Why do you insist Alana is not real?': Visitors' Perceptions of the Fictionality of Andi and Lance Olsen's 'There's No Place Like Time' Exhibition. In Style and Reader Response: Minds, Media, Methods, ed. Alice Bell, Sam Browse, Alison Gibbons, and David Peplow, 101-121. Amsterdam: John Benjamins.

Green, Melanie C., Jennifer Garst, Timothy C. Brock, and Sungeun Chung. 2006. Fact Versus Fiction Labeling: Persuasion Parity Despite Heightened Scrutiny of Fact. Media Psychology 8: 267-285.

Hunt, Celia. 2004. Writing and Reflexivity: Training to Facilitate Writing for Personal Development. In Creative Writing in Health and Social Care, ed. Fiona Sampson, 154-169. London: Jessica Kingsley.

- 2018. Autofiction as a Reflexive Mode of Thought: Implications for Personal Development. In Autofiction in English, ed. Hywel Dix, 179-196. Cham: Palgrave Macmillan.

Kitamura, Katie. 2018. Anxieties of Influence. The New York Times Book Review, October 7 .

Konstantinou, Lee. 2018. Neorealist Fiction. In American Literature in Transition: 2000-2010, ed. Rachel Greenwald Smith, 109-124. Cambridge: Cambridge University Press.

Laing, Olivia. 2018a. Crudo. London: Picador.

- 2018b. Becoming Kathy Acker: An Interview with Olivia Laing. Interview by Chris Kraus, The Paris Review, September 11, 2018. https://www.theparisreview.org/blog/2018/09/11/becoming-kathy-acker-an-interview-witholivia-laing/. Accessed Apr 1, 2021.

- 2018c. Olivia Laing: 'I Stopped Being Able to Distinguish News from Rumour, Paranoia and Supposition.' Interview by Anna Leszkiewicz, New Statesman, November 2, 2018. https://www.newstatesman.com/culture/ books/2018/11/olivia-laing-i-stopped-being-able-distinguish-news-rumourparanoia-and. Accessed Mar 30, 2021.

Larsen, Steen F., and Uffe Seilman. 1988. Personal Remindings While Reading Literature. Text 8 (4): 411-430. 
Lejeune, Philippe. 1989. The Autobiographical Pact. In On Autobiography, translated by Katherine Leary, 3-30. Minneapolis: University of Minnesota Press.

Lerner, Ben. 2014a. 10:04. London: Granta.

2014b. Ben Lerner. Interview by Tao Lin, The Believer, September 4, 2014. https://believermag.com/an-interview-with-ben-lerner/. Accessed Apr 1, 2021.

Mason, Jessica. 2019. Intertextuality in Practice. Amsterdam; Philadelphia, PA: John Benjamins.

Nielsen, Henrik Skov. 2011. What's in a Name? Double Exposures in Lunar Park. In Bret Easton Ellis: American Psycho/Glamorama/Lunar Park, ed. Naomi Mandel, 129-142. London: Continuum.

Nielsen, Henrik Skov, James Phelan, and Richard Walsh. 2015. Ten Theses about Fictionality. Narrative 23 (1): 74-100.

Pettersson, Torsten. 2016. Fictionality and the Empirical Study of Literature. CLCWeb: Comparative Literature and Culture 18 (2). https://docs.lib.purdue.edu/clcweb/vol18/iss2/3/. Accessed Mar 30, 2021.

Prentice, Deborah A., and Richard J. Gerrig. 1999. Exploring the Boundary between Fiction and Reality. In Dual-Process Theories in Social Psychology, ed. Shelley Chaiken and Yaacov Trope, 529-546. New York: Guilford Press.

Roth, Philip. 1988a. PW Interviews: Philip Roth. Interview by Katharine Weber. In Conversations with Philip Roth, edited by George J. Searles, 220-225. Jackson: University Press of Mississippi, 1992. Reprinted from the August 26, 1988 issue of Publishers Weekly.

- 1988b. The Facts: A Novelist's Autobiography. London: Penguin Random House.

Seilman, Uffe, and Steen F. Larsen. 1989. Personal Resonance to Literature: A Study of Remindings While Reading. Poetics 18 (1): 165-177.

Srikanth, Siddharth. 2019. Fictionality and Autofiction. Style 63 (3): 344-363.

Stockwell, Peter. 2019. Cognitive Poetics: An Introduction. 2nd ed. London; New York: Routledge.

Walker, Amelia. 2018. Autofictionalizing Reflective Writing Pedagogies: Risks and Possibilities. In Autofiction in English, ed. Hywel Dix, 198-215. Cham: Palgrave Macmillan.

Wirth-Nesher, Hana. 2007. Roth's Autobiographical Writings. In The Cambridge Companion to Philip Roth, ed. Timothy Parrish, 158-172. Cambridge: Cambridge University Press.

Worthington, Marjorie. 2018. The Story of "Me": Contemporary American Autofiction. Lincoln, NE: University of Nebraska Press.

Yang, Jie, and Jin Xue. 2014. Distinguishing Different Fictional Worlds during Sentence Comprehension: ERP Evidence. Psychophysiology 51: 42-51. 
2015. Reality/Fiction Distinction and Fiction/Fiction Distinction during Sentence Comprehension. Universal Journal of Psychology 3 (6): 165-175.

Zipfel, Frank. 2005. Autofiction. In Routledge Encyclopedia of Narrative Theory, ed. David Herman, Manfred Jahn, and Marie-Laure Ryan, 36-37. London: Routledge.

Zwaan, Rolf A. 1994. Effect of Genre Expectations on Text Comprehension. Journal of Experimental Psychology: Learning, Memory and Cognition 20: 920-933.

Open Access This chapter is licensed under the terms of the Creative Commons Attribution 4.0 International License (http://creativecommons.org/licenses/ by $/ 4.0 /$ ), which permits use, sharing, adaptation, distribution and reproduction in any medium or format, as long as you give appropriate credit to the original author(s) and the source, provide a link to the Creative Commons licence and indicate if changes were made.

The images or other third party material in this chapter are included in the chapter's Creative Commons licence, unless indicated otherwise in a credit line to the material. If material is not included in the chapter's Creative Commons licence and your intended use is not permitted by statutory regulation or exceeds the permitted use, you will need to obtain permission directly from the copyright holder.

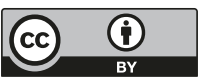

